Jurnal Keperawatan Silampari

Volume 5, Nomor 1, Desember 2021

e-ISSN: 2581-1975

p-ISSN: 2597-7482

DOI: https://doi.org/10.31539/jks.v5i1.2683

\title{
ADAPTASI FISIOLOGIS BAYI BARU LAHIR MELALUI PERSALINAN NORMAL DENGAN LOTUS BIRTH DAN TANPA LOTUS BIRTH
}

\author{
Susi Sastika Sumi ${ }^{1}$, Wa Mina La Isa ${ }^{2}$ \\ Sekolah Tinggi Ilmu Kesehatan Nani Hasanuddin Makassar ${ }^{1,2}$ \\ susisastikasumi@yahoo.co.id ${ }^{1}$
}

\begin{abstract}
ABSTRAK
Penelitian ini bertujuan untuk mengetahui perbedaan adaptasi fisiologis bayi baru lahir melalui persalinan normal dengan lotus birth dan tanpa lotus birth di Puskesmas Kandai Kota Kendari. Metode yang digunakan adalah penelitian kuantitatif menggunakan comparative study dengan pendekatan cross sectional. Hasil penelitian terdapat perbedaan adaptasi fisiologis (frekuensi denyut jantung, frekuensi pernapasan, frekuensi termogulasi atau suhu tubuh) bayi baru lahir melalui persalinan normal dengan lotus birth dan tanpa lotus birth. Data statistic responden yang diperoleh dari setiap system fisiologi bayi baru lahir menunjukan nilai p 0,013. Simpulan, terdapat perbedaan adaptasi fisiologis bayi baru lahir melalui persalinan normal dengan lotus birth dan tanpa lotus birth di Puskesmas Kandai Kota Kendari.
\end{abstract}

Kata Kunci: Adaptasi Fisiologis, Bayi Baru Lahir, Lotus Birth, Tanpa Lotus Birth

\begin{abstract}
This study aims to determine the differences in the physiological adaptation of newborns through expected delivery with lotus birth and without lotus birth at Kandai Public Health Center, Kendari City. The method used is quantitative research using a comparative study with a cross-sectional approach. The results showed differences in physiological adaptation (heart rate, respiratory rate, thermoregulated frequency, or body temperature) of newborns through expected delivery with lotus birth and without lotus birth. Respondent statistical data obtained from each physiological system of newborns showed a p-value of 0.013. In conclusion, there are differences in the physiological adaptation of newborns through expected delivery with lotus birth and without lotus birth at the Kandai Public Health Center, Kendari City.
\end{abstract}

Keywords: Physiological Adaptation, Newborn, Lotus Birth, Without Lotus Birth

\section{PENDAHULUAN}

Proses kelahiran merupakan pengalaman yang sangat berharga bagi ibu dan bayi. Proses persalinan dapat dengan berbagai cara yaitu persalinan normal, anjuran, tindakan dan pembedahan. Persalinan normal dapat juga ditambah dengan berbagai metode persalinan salah satunya persalinan lotus. Lotus Birth (Persalinan lotus) adalah persalinan normal tetapi tidak memotong tali pusat, jadi tali pusat dan plasenta masih terhubung dengan bayi sampai mengering dan lepas dengan sendirinya (Hanum \& Nasution, 2019; Sugarni et al., 2018; Setyorini, 2015). 
Manurut Cunningham (2016) lotus birth atau sering disebut dengan persalinan teratai adalah suatu metode persalinan dengan meninggalkan tali pusat yang belum dipotong sampai pemisahan terjadi secara alami. Kemudian tali pusat mengering dan akhirnya lepas dari umbilicus. Pelepasan tersebut terjadi 3-10 hari setelah lahir.

Lotus birth menjadi salah satu metode persalinan yang dilakukan dalam proses persalinan normal yaitu dengan menunda pemotongan tali pusat sehingga plasenta dan tali pusat tetap terhubung dengan bayi. World Health Organization (WHO) menyebutkan bahwa dengan menunda penjepitan tali pusat dapat meningkatkan suplay zat besi sehingga mengurangi kejadian anemia pada bayi sebesar 60\%, mengurangi pendarahan intraventrikuler pada bayi prematur sebesar 59\%, mengurangi enterocolitis nekrotik pada bayi premetur sebesar $62 \%$, mengurangi sepsis, dan mengurangi kebutuhan transfuse darah pada bayi prematur (WHO, 2018).

Bayi yang baru lahir beberapa saat atau beberapa jam pertama akan melalui kehidupan ekstrim dimana masa yang paling dinamis dari seluruh siklus kehidupan akibat berpindah dari ketergantungan total ke kemandirian fisiologis, proses ini dikenal dengan periode transisi (Padila et al., 2018). Oleh karena itu pada setiap kelahiran penting bagi tenaga kesehatan untuk memikirkan tentang faktor-faktor kehamilan atau persalinan yang dapat menyebabkan gangguan dijam pertama kehidupan diluar rahim seperti partus lama, trauma lahir, infeksi, keluar mekunium, dan penggunaan obat-obatan, sehingga angka kematian ibu dan bayi dapat diminimalisir. Kematian dan kesakitan pada ibu hamil dan bersalin, ibu nifas serta bayi baru lahir sejak lama telah menjadi masalah di negara berkembang seperti Indonesia (Kementerian Kesehatan RI, 2018; Padila et al., 2021).

Angka Kematian Ibu (AKI) di Indonesia per 100.000 kelahiran hidup tahun 2007 sebanyak 277 kematian, tahun 2012 sebanyak 359 kematian dan pada tahun 2015 menunjukkan penurunan yaitu sebanyak 305 kematian (Profil Kesehatan Indonesia, 2016). Angka kematian bayi per 1000 kelahiran hidup tahun 2007 sebanyak 44 kematian, tahun 2012 sebanyak 40 kematian dan pada tahun 2015 sebanyak 26 kematian (Profil Kesehatan Indonesia, 2018). Bila dibandingkan dengan target MDG's 2015 yaitu sebesar 102 AKI/100.000 KH, dapat dikatakan bahwa target tersebut belum tercapai (Profil Kesehatan Sulawesi Tenggara, 2018).

Sebagai salah satu upaya penurunan angka kematian bayi dan juga angka kematian ibu, saat ini mulai berkembang metode persalinan gentle birth antara lain water birth, hypnobirthing, dan lotus birth. Lotus birth yang diharapkan dapat membantu mengurangi trauma persalinan pada ibu dan bayi yang dilakukan secara tenang, lembut, santun dan memanfaatkan semua unsur alami dalam tubuh, bebas dari intervensi, dan minim trauma baik pada ibu maupun bayi. Metode ini sebenarnya bagian dari budaya terdahulu dan saat ini mulai dikembangkan di Amerika. (Syaifuddin, 2020).

Berdasarkan studi pendahuluan yang telah dilakukan di Puskesmas Kandai Kota Kendari jumlah keseluruhan persalinan normal tahun 2015 sebanyak 163 persalinan, persalinan normal dengan lotus birth sebanyak $152(93,3 \%)$ dan persalinan normal dengan pemotongan tali pusat sebanyak $11(6,7 \%)$. Tahun 2016 sebanyak 152 persalinan dengan metode lotus birth sebanyak $143(94,1 \%)$ dan persalinan normal dengan pemotongan tali pusat sebanyak 9 (5.9\%). Tahun 2017 sebanyak 173 persalinan. Persalinan normal dengan metode lotus birth sebanyak $158(91,3 \%)$ dan persalinan normal dengan pemotongan tali pusat sebanyak $15(8,7 \%)$.

Penelitian terkait metode lotus birth telah dilakukan oleh beberapa peneliti sebelumnya salah satunya adalah yang dilakukan oleh Herlyssa et al., (2015) yang memperoleh hasil penelitian berupa adanya perbedaan pertumbuhan yang dialami oleh bayi 
baru lahir pada metode lotus birth. Sejalan dengan penelitian yang dilakukan Sugarni et al., (2018) yang menunjukkan bahwa terdapat perbedaan bermakna antara lotus birth dengan tanpa lotus birth pada persalinan normal terhadap adaptasi fisiologis bayi baru lahir.

Penelitian sebelumnya tentang lotus birth yang sudah pernah diteliti hanya melihat pertumbuhan bayi baru lahir, sedangkan pada penelitian ini lebih berfokus pada adaptasi fisiologis bayi baru lahir dengan membandingkan kedua metode persalinan berupa lotus birth dan tanpa lotus birth.

\section{METODE PENELITIAN}

Penelitian ini menggunakan jenis penelitian comparative study yaitu metode studi perbandingan dengan cara membandingkan dan melihat persamaan antara persalinan normal dengan lotus birth dan tanpa lotus birth terhadap adaptasi fisiologis bayi baru lahir menggunakan pendekatan cross sectional.

Penelitian ini dilakukan mulai dari 19 Oktober 2020 - 15 Desember 2020 di Puskesmas Kandai Kota Kendari dengan jumlah populasi sebanyak 30 ibu bersalin. Pengambilan sampel menggunakan total sampling yaitu 30 responden karena jumlah populasi kurang dari 100. Data penelitian ini dikumpulkan dengan dua cara. Pertama dengan wawancara terstruktur yang telah peneliti siapkan. Instrumen penelitian berupa kuesioner dengan pertanyaan-pertanyaan tertulis. Kedua observasi dimana peneliti terlibat langsung pada kegiatan yang diteliti/diamati.

Analisis data menggunaka uji chi-square yang merupakan salah satu jenis uji kompartif non peremetris digunakan untuk menguji dua kelompok data baik variable independent maupun variable dependen. Dasar uji ini adalah membandingkan perbedaan hasil observasi dengan frekuensi yang diharapkan menggunakan derajat kepercayaan $95 \%$.

\section{HASIL PENELITIAN Analisi Univariat}

Tabel. 1

Distrubusi Frekuensi Responden Berdasarkan Usia, Paritas, Pendidikan, Pekerjaan, dan Metode Persalinan

\begin{tabular}{|c|c|c|c|}
\hline No & Karakteristik & Frekuensi $(f)$ & Persentase $(\%)$ \\
\hline \multirow[t]{3}{*}{1.} & Usia (tahun) & & \\
\hline & $20-35$ & 23 & 86,4 \\
\hline & $<20$ dan $>35$ & 7 & 13,6 \\
\hline \multirow[t]{3}{*}{2.} & Paritas & & \\
\hline & Primipara & 9 & 22,7 \\
\hline & Multipara & 21 & 77,3 \\
\hline \multirow[t]{3}{*}{3.} & Pendidikan & & \\
\hline & Pendidkan tinggi & 22 & 81,8 \\
\hline & Pendidikan rendah & 8 & 18,2 \\
\hline \multirow[t]{3}{*}{4.} & Pekerjaan & & \\
\hline & Bekerja & 12 & 36,4 \\
\hline & Tidak bekerja & 18 & 63,6 \\
\hline \multirow[t]{4}{*}{5.} & Metode persalinan & & \\
\hline & Louts birth & 15 & 50 \\
\hline & Tanpa lotus birth & 15 & 50 \\
\hline & Jumlah & 30 & 100 \\
\hline
\end{tabular}


Berdasarkan tabel 1 diperoleh data bahwa mayoritas responden berada pada rentan usia 20-35 tahun (86,4\%), sedangkan usia usia responden dibawah 20 tahun atau lebih dari 35 tahun hanya sebanyak $(13,6)$. Berdasarkan paritas atau jumlah dalam melakukan persalinan menunjukan bahwa dari 30 responden, mayoritas multipara atau sudah melakukan persalinan lebih dari satu kali $(77,3 \%)$, sedangkan untuk primipara sebanyak $(22,7 \%)$.

Penelitian yang dilakukan pada 30 responden diperoleh hasil mayoritas memiliki Pendidikan tinggi yaitu tamat SMA hingga perguruan tinggi sebanya $22(81,8 \%)$, dan yang berpendidikan rendah dalam hal ini hanya tamat SD atau SMP ada $8(18,2 \%)$. Hasil penelitian yang diperoleh dari 30 responden mayoritas tidak bekerja atau tidak memiliki penghasilan sendiri sebanyak $18(63,6 \%)$, sedangkan yang bekerja atau memiliki penghasilan sendiri sebanyak $12(36,4 \%)$. Berdasarkan metode persalinan memiliki jumlah responden yang sama baik dengan lotus birth maupun tanpa lotus birth yaitu masingmasing berjumlah $15(50 \%)$ dengan total reponden 30 .

\section{Analisis Bivariat}

Tabel. 2

Distribusi Frekuensi Denyut Jantung

\begin{tabular}{|c|c|c|c|c|c|c|c|c|}
\hline \multirow{3}{*}{ Metode } & \multicolumn{6}{|c|}{ Frekuensi Denyut Jantung } & \multirow{3}{*}{$X^{2}$} & \multirow{3}{*}{$\rho_{\text {value }}$} \\
\hline & \multicolumn{2}{|c|}{$\begin{array}{c}\text { Normal } \\
(100-160)\end{array}$} & \multicolumn{2}{|c|}{$\begin{array}{c}\text { Tidak } \\
\text { Normal }(<100 \\
\text { dan }>160)\end{array}$} & \multicolumn{2}{|c|}{ Total } & & \\
\hline & $\mathrm{f}$ & $\%$ & $\mathrm{f}$ & $\%$ & $\mathrm{f}$ & $\%$ & & \\
\hline Lotus Birth & 7 & 31,2 & 8 & 100 & 15 & 50 & & \\
\hline Non Lotus Birth & 15 & 68,8 & 0 & 0 & 15 & 50 & 8,250 & 0,005 \\
\hline Jumlah & 22 & 100 & 8 & 100 & 30 & 100 & & \\
\hline
\end{tabular}

Data tabel 2 menunjukkan bahwa dari 15 responden mengalami lotus birth terdapat 7 responden $(31,2 \%)$ yang memiliki frekuensi denyut jantung berkisar 100-160 kali per menit dan 15 responden $(68,8 \%)$ pada metode non lotus birth yang memiliki frekuensi denyut jantung berkisar 100-160 permenit, sedangkan untuk kategori $<100$ dan $>160$ pada lotus birth terdapat 8 responden (100\%) dan non lotus birth tidak terdapat responden $(0 \%)$ yang memiliki frekuensi denyut jantung berkisar $<100$ dan $>160$.

Tabel. 3

Distribusi Frekuensi Pernapasan

\begin{tabular}{|c|c|c|c|c|c|c|c|c|}
\hline \multirow{3}{*}{ Metode } & \multicolumn{6}{|c|}{ Frekuensi Pernapasan } & \multirow[t]{3}{*}{$X^{2}$} & \multirow{3}{*}{$\rho_{\text {value }}$} \\
\hline & \multicolumn{2}{|c|}{$\begin{array}{r}\text { Normal } \\
(40-60) \\
\end{array}$} & \multicolumn{2}{|c|}{$\begin{array}{l}\text { Tidak Normal } \\
(<40 \text { dan }>60)\end{array}$} & \multicolumn{2}{|c|}{ Total } & & \\
\hline & $f$ & $\%$ & $\mathrm{f}$ & $\%$ & $\mathrm{f}$ & $\%$ & & \\
\hline Lotus Birth & 8 & 35,3 & 7 & 100 & 15 & 50 & & \\
\hline Non Lotus Birth & 15 & 64,7 & 0 & 0 & 15 & 50 & 6,471 & 0,013 \\
\hline Jumlah & 23 & 100 & 7 & 100 & 30 & 100 & & \\
\hline
\end{tabular}

Berdasarkan tabel 3 menunjukkan bahwa jumlah responden dengan frekuensi pernapasan berkisar 40-60 pada metode lotus birth sebanyak 8 responden $(35,3 \%)$ dan pada metode non lotus birth sebanyak 15 responden $(64,7 \%)$. Sedangkan jumlah responden 
dengan frekuensi pernapasan yang berkisar $<40$ dan $>60$ pada metode lotus birth 7 (100\%) dan pada metode non lotus birth tidak terdapat responden yang memiliki frekuensi pernapasan $<40$ dan $>60$.

Tabel. 4

Distribusi Frekuensi

Suhu Tubuh/Termogulasi

\begin{tabular}{|c|c|c|c|c|c|c|c|c|}
\hline \multirow{3}{*}{ Metode } & \multicolumn{6}{|c|}{ Frekuensi Termogulasi } & \multirow{3}{*}{$X^{2}$} & \multirow{3}{*}{$\rho_{\text {value }}$} \\
\hline & \multicolumn{2}{|c|}{$\begin{array}{c}\text { Normal } \\
\left(36,5^{\circ} \mathrm{C}-37,5^{\circ} \mathrm{C}\right)\end{array}$} & \multicolumn{2}{|c|}{$\begin{array}{l}\text { Tidak Normal } \\
\left(<36,5^{\circ} \mathrm{C} \text { dan }\right. \\
\left.>37,5^{\circ} \mathrm{C}\right)\end{array}$} & \multicolumn{2}{|c|}{ Total } & & \\
\hline & $\mathrm{f}$ & $\%$ & $\mathrm{f}$ & $\%$ & $\mathrm{f}$ & $\%$ & & \\
\hline Lotus Birth & 8 & 35,3 & 7 & 100 & 15 & 50 & & \\
\hline Non Lotus Birth & 15 & 64,7 & 0 & 0 & 15 & 50 & 6,471 & 0,013 \\
\hline Jumlah & 23 & 100 & 7 & 100 & 30 & 100 & & \\
\hline
\end{tabular}

Berdasarkan tabel 4 menunjukkan bahwa jumlah responden yang memiliki frekuensi suhu tubuh normal yang berkisar $36,5^{\circ} \mathrm{C}-37,5^{\circ} \mathrm{C}$ sebanyak 23 responden, dimana yang mengalami lotus birth sebanyak $8(35,3 \%)$ sedangkan untuk non lotus birth sebanyak 15 $(64,7 \%)$. Kemudian jumlah responden yang memiliki frekuensi suhu tubuh tidak normal yang berkisar $<36,5^{\circ} \mathrm{C}$ dan $>37,5^{\circ} \mathrm{C}$ sebanyak 7 responden dan untuk metode non lotus birth tidak terdapat responden dengan frekuensi $<36,5^{\circ} \mathrm{C}$ dan $>37,5^{\circ} \mathrm{C}$.

\section{PEMBAHASAN}

\section{Denyut Jantung}

Sirkulasi darah dan denyut jantung merupakan komponen yang saling terkait dari sistem kardiovaskuler dan oleh karena itu, keterkaitan atau hubungan darah dan jantung sangat penting sehingga dapat mempengaruhi satu sama lainnya. Didalam sistem kardiovaskuler ini ada pembuluh darah sebagai media sirkulasi darah keseluruh tubuh, karena pembuluh darah merupakan keseluruhan sistem peredaran darah yang terdiri dari arteri, arteriola, kapiler, venula dan vena. Darah mengalir dari plasenta ke janin melalui umbilikus yang terdapat dalam tali pusat. Jumlah yang mengalir melalui tali pusat sekitar $125 \mathrm{ml} / \mathrm{kg} / \mathrm{BB} / \mathrm{m}$ atau sekita $500 \mathrm{ml}$ permenit (Ratnasari et al., 2013).

Pada metode lotus birth dimana tidak dilakukan pemotongan tali pusat ataupun penjepitan tali pusat saat lahir sehingga dapat meningkatkan suplay zat besi pada bayi. Bayi akan menerima tambahan 50-100 ml darah yang dikenal dengan transfusi plasenta. Darah ini mengandung zat besi, sel darah merah, sel induk, sel batang dan bahan gizi lain, yang akan bermanfaat bagi bayi dalam tahun pertama kehidupannya (Ratnasari et al., 2013).

Berdasarkan hasil penelitian frekuensi denyut jantung pada responden yang mengalami lotus birth lebih ditinggi dibandingkan dengan responden non lotus birth. Sehingga dapat disimpulkan frekuensi denyut jantung pada lotus birth dan tanpa lotus birth berbeda. Hal ini didukung dengan hasil uji statistik Chi-Square Test dengan taraf kepercayaan 95\% $(\alpha=0,05), \mathrm{df}=1$, menunjukkan bahwa $\mathrm{x}^{2}=8,50$ dan $\rho_{\text {value }}=0,005$, jadi nilai $\mathrm{p}<$ dari $\alpha$ sehingga adanya perbedaan bermakna antara yang mengalami lotus birth dan non lotus birth terhadap denyut jantung di Puskesmas Kandai Kota Kendari Tahun 2020.

Sejalan dengan penelitian Sugarni tahun 2018 yang menunjukkan bahwa ada pengaruh denyut jantung bayi antara lotus birth dan tanpa lotus birth. Frekuensi jantung bayi cepat sekitar 120-160 kali per menit, serta berfluktuasi selaras dengan fungsi 
pernsapasan bayi, aktivitas atau dalam kondisi tidur atau istirahat. Peredaran darah perifer masih kurang optimal. Ini mengakibatkan sianosis ringan di tangan,kaki, dan daerah di sekelilingnya. Terdapat bercakbercak di seluruh tubuh jika kulit terpajan. Tekanan darah berfluktuasi sesuai (Harun, 2019; Sugarni et al., 2018).

\section{Pernapasan}

Selama kehamilan organ yang berperan dalam respirasi janin sampai janin lahir adalah placenta. Pada saat bayi lahir, iaharus segera bernafas. Rangsangan yang menstimulasi neonates untuk bernafas pertama kali, diantaranya; peristiwa mekanis seperti penekanan toraks pada proses kelahiran pervagina dan tekanan yang tinggi pada toraks tersebut tiba-tiba hilang ketika bayi lahir disertai oleh stimulus fisik, nyeri, cahaya suara menyebabkan perangsangan pusat pernafasan. Pada metode lotus birth bayi akan menerima tambahan 50-100 ml darah yang dikenal dengan transfusi plasenta. Sehingga ada peningkatan aliran darah ke paru yang akan memperlancar pertukaran gas dalam alveolus yang menjadikan frekuensi pernapasa lebih tinggi dibandingkan dengan persalinan umum yang dilakukan pemotongan tali pusat (Rachana, 2021)

Hasil penelitian yang dilakukan dengan uji statistik Chi-Square Test dengan taraf kepercayaan 95\% $(\alpha=0,05), \mathrm{df}=1$, menunjukkan bahwa $\mathrm{x}^{2}=6,471$ dan nilai $\mathrm{p}=0,013$ jadi nilai $\mathrm{p}<$ dari $\alpha$ sehingga Ha diterima dan $\mathrm{H} 0$ ditolak menunjukkan adanya perbedaan bermakna antara yang menggunakan metode lotus birth dan non lotus birth terhadap frekuensi pernapasan di Puskesmas Kandai Kota Kendari Tahun 2020.

Selama kehamilan organ yang berperan dalam respirasi janin sampai janin lahir adalah placenta. Pada saat bayi lahir, iaharus segera bernafas. Rangsangan yang menstimulasi neonatus untuk bernafas pertama kali, diantaranya; peristiwa mekanis seperti penekanan toraks pada proses kelahiran pervagina dan tekanan yang tinggi pada toraks tersebut tiba-tiba hilang ketika bayi lahir disertai oleh stimulus fisik, nyeri, cahaya suara menyebabkan perangsangan pusat pernafasan. Pada saat bayi mencapai cukup bulan, kurang dari $100 \mathrm{ml}$ cairan paru-paru terdapat di dalam nafasnya. Selama proses kelahiran,kompresi dinding dada akan membantu pengeluaran sebagian dari cairan ini dan lebihnya akan diserap oleh sirkulasi pulmonum serta sistem limphatik setelah kelahiran bayi. Tarikan nafas yang pertama pada bayi baru lahir, udara di ruangan mulai mengisi saluran napas besar trakhea neonatus dan bronkus. Oksigenasi yang memadai merupakan faktor yang sangat penting dalam mempertahankan kecukupan pertukaran udara. Peningkatan aliran darah paru akan memperlancar pertukaran gas dalam alveolus dan menghilangkan cairan paru (Sugarni et al., 2018).

\section{Suhu Tubuh}

Bayi baru lahir memilki kecenderungan cepat stress akibat perubahan suhu lingkungan, karena belum dapat mengatur suhu tubuh sendiri (Padila et al., 2019). Pada saat bayi meninggalkan lingkungan rahim ibu yang bersuhu rata-rata $37^{\circ} \mathrm{C}-38^{\circ} \mathrm{C}$, kemudian bayi masuk ke dalam lingkungan. Suhu ruangan persalinan yang suhu $25^{\circ} \mathrm{C}$ sangat berbeda dengan suhu di dalam rahim. Namun pada bayi yang mengalami lotus birth tidak jauh berbeda pada saat bayi belum meninggalkan lingkungan rahim karena masih adanya suplai tambahan darah dari plasenta yang disebut transfusi plasenta. Hasil uji statistik Chi-Square Test dengan taraf kepercayaan 95\% $(\alpha=0,05)$, df $=1$, menunjukkan bahwa $x^{2}=6,471$ dan nilai $\mathrm{p}=0,013$, jadi nilai $\mathrm{p}<$ dari $\alpha$ sehingga menunjukkan bahwa adanya perbedaan bermakna antara yang mengalami lotus birth dan non lotus birth terhadap termogulasi frekuensi pernapasan di Puskesmas Kandai Kota Kendari Tahun 2020. 
Bayi baru lahir memilki kecenderungan cepat stress akibat perubahan suhu lingkungan, karena belumdapat mengatur suhu tubuh sendiri. Padasaat bayi meninggalkan lingkungan rahim ibu yang bersuhu rata-rata $37^{\circ} \mathrm{C}-38^{\circ} \mathrm{C}$, kemudian bayi masuk ke dalam lingkungan. Suhu ruangan persalinan yang suhu $25^{\circ} \mathrm{C}$ sangat berbeda dengan suhu di dalam rahim. Neonatus dapat menghasilkan panas dalam jumlah besar dengan cara; menggigil, aktifitas otot dan termogenesis (produksi panas tanpa menggigil). Sehingga dapat menyebabkan peningkatan metabolisme dan mengakibatkan peningkatan penggunaan oksigen oleh neonatus. Oleh karena itu kehilangan panas pada neonatus berdampak pada hipoglikemi, hipoksia dan asidosis (Sugarni et al., 2018; Setyorini, 2015).

Metode lotus birth dianggap dapat menambah kekebalan tubuh dan mencegah anemia pada bayi baru lahir. Dengan metode ini, bayi diharapkan mendapatkan lebih banyak darah yang mengandung oksigen, makanan dan antibodi. Namun perlu ditegaskan bahwa plasenta bisa memproduksi antibodi hanya bila masih berada di dalam rahim ibu. Apabila sudah di berada di luar rahim ibu maka secara otomatis tidak dapat memproduksi antibodi lagi. Darah yang masih ada di plasenta hanyalah sisa-sisa yang jumlahnya tidak seberapa (Doktersehat, 2018).

\section{SIMPULAN}

Terdapat perbedaan adaptasi fisiologis (frekuensi denyut jantung, frekuensi pernapasan, frekuensi termogulasi atau suhu tubuh) bayi baru lahir melalui persalinan normal dengan lotus birth dan tanpa lotus birth.

\section{SARAN}

Bagi petugas kesehatan Puskesmas Kandai agar tetap memberikan konseling atau informasi seputar lotus birth dengan tujuan agar metode lotus birth dikenal banyak orang.

Bagi tenaga Kesehatan khususnya dokter obgin, bidan, maupun perawat yang terlibat langsung dalam pelaksanaan metode lotus birth lebih meningkatkan pengetahuan dan keterampilan melalui pelatihan serta penyuluhan kepada kader posyandu terutama masalah perubahan adaptasi fisiologis bayi baru lahir.

\section{DAFTAR PUSTAKA}

Cunningham, E. (2016). Is Water Birth Natural for the Fetus? MIDIRS Midwifery Digest, 26(2), 203-208. http://ovidsp.ovid.com/ovidweb.cgi?T=JS\&PAGE=reference $\& D=0 v f t r \& N E W S=$ N\&AN=00115386-201626020-00015

Doktersehat. (2018). Amankah Melahirkan dengan Metode Lotus Birth?. Retrieved fromhttps://doktersehat.com/aman kah-melahirkan-dengan-metodelotus-birth/

Hanum, P., \& Nasution, S. W. (2019). Efektifitas Metode Lotus Birth terhadap Kejadian Anemia Defisiensi Zat Besi pada Bayi. Jumatik: Jurnal Ilmiah Penelitian Kesehatan, 4(2),

213-219. http://jurnal.uinsu.ac.id/index.php/kesmas/article/view/5591

Harun, S. N. (2019). Adaptasi Fisiologis Bayi Baru Lahir dengan Metode Lotus Birth dan Tanpa Lotus Birth di Klinik Anny Raharjo dan RSU Budi Kemuliaan Bulan Maret 2019. Sekolah Tinggi Ilmu Kesehatan Budi Kemuliaan

Herlyssa, H., Mulyati, S., \& Martini, R. (2015). Perbedaan Pertumbuhan Bayi Baru Lahir Pada Metode Lotus Birth.Jurnal Ilmu dan Teknologi Kesehatan, 2(2), 1-9. https://ejurnal.poltekkesjakarta3.ac.id/index.php/jitek/article/view/33 
Kementerian Kesehatan RI. (2018). Profil Kesehatan Indonesia. Jakarta. https://pusdatin.kemkes.go.id/folder/view/01/structure-publikasi-data-pusat-datadan-informasi.html

Padila, P., \& Agustien, I. (2019). Suhu Tubuh Bayi Prematur di Inkubator Dinding Tunggal dengan Inkubator Dinding Tunggal Disertai Sungkup. Jurnal Keperawatan Silampari, 2(2), 113-122. https://doi.org/10.31539/jks.v2i2.651

Padila, P., Amin, M., \& Rizki, R. (2018). Pengalaman Ibu dalam Merawat Bayi Preterm yang Pernah Dirawat di Ruang Neonatus Intensive Care Unit Kota Bengkulu. Jurnal Keperawatan Silampari, 1(2), 1-16. https://doi.org/10.31539/ jks.v1i2.82

Padila, P., Panzilion, P., Andri, J., Nurhayati, N., \& J, H. (2021). Pengalaman Ibu Usia Remaja Melahirkan Anak di Masa Pandemi COVID-19. Journal of Telenursing (JOTING), 3(1), 63-72. https://doi.org/10.31539/joting.v3i1.2075

Profil Kesehatan Sulawesi Tenggara. (2018). Profil Kesehatan Sulawesi Tenggara https://pusdatin.kemkes.go.id/index.php?category=profil-kesehatankabupaten\&provid=PV-027

Puskesmas Kandai. (2019). Profil Puskesmas Kandai. Kendari

Rachana, S. (2021). Lotus Birth. Australia: Greenwood Press

Ratnasari, L., Subekti, E. L., Wahyundari, A., \& Eko, N. (2013).Pengaruh Persalinan Lotus Birth terhadap Lama Pelepasan Plasenta, Lama Pelepasan Tali Pusat dan Keberhasilan Bounding Attachment. Jurnal Kebidanan, 5(2), 46-56. http://ejurnal.stikeseub.ac.id/index.php/jkeb/article/view/122

Saifuddin, S.(2020). Ilmu Kebidanan.Jakarta: Yayasan Bina Pustaka

Setyorini, Y. (2015). Pengaruh Metode Persalinan Lotus terhadap Adaptasi Bayi Baru Lahir. Jurnal Terpadu Ilmu Kesehatan, 4.Available at : jurnal.Poltekkessolo.ac.Id/index.Php/Int/article/viewFile/270/243

Sugarni, M., Askrening, A., \&Syahrianti, S. (2018). Perbedaan Lotus Birth dengan Tanpa Lotus Birth pada Persalinan Normal terhadap Adaptasi Fisiologis Bayi Baru Lahir di Puskesmas Kandai Kota Kendari. Potiteknik Kesehatan Kendari. http://repository.poltekkes-kdi.ac.id/575/1/SKRIPSI\%20PDF\%20LENGKAP.pdf

WHO. (2018). Tren Persalinan. www.academia.Edu/9825392/minikti_trenpersalinan. (Diakses tanggal 27/02/2020) 